\title{
BEAN SEED QUALITY: ASSOCIATED GERMINABILITY AND FIELD PERFORMANCE
}

\author{
Farouk M. Gadallah \\ Botany Dept., Fac. Agric., Fayoum University, Egypt
}

\section{ABSTRACT:}

This work aimed to investigate the influence of different levels of bean seed quality on germinability (laboratory study), growth, yield and its components (green pod and dry seed yield) under field conditions. To achieve this study, the seed lot of bean (cv. Giza 3) was manually separated into three classes; light (33.79-38.02 $100^{-1}$ seeds; in 2005 season) and (34.39-37.13g 100 seeds; in 2006 season); ungraded (37.70-42.85g $100^{-1}$ seeds; in 2005 season) and (40.02-49.81g $100^{-1}$ seeds; in 2006 season) and heavy (47.20-57.60g $100^{-1}$ seeds; in 2005 season) and (48.75$57.13 \mathrm{~g} 100^{-1}$ seeds; in 2006 season). Under field conditions, seeds of bean were sown during two summer successive seasons of 2005 and 2006 at the experimental station, Faculty of Agriculture, Fayoum University, Egypt. The obtained data could be summarized as follows:

High-weight class of bean seeds usually exhibited faster and more uniform rates of radicle emergence (as indicator of germination) than low-weight and ungraded ones. Seedling produced from heavier seeds had greater rates of QI, VI, length of radical hypocotyl and accumulation of fresh and dry weights than those from light seeds. The water uptake\%, EC and the quantity of materials leached from the seed $\left(\mathrm{Na}, \mathrm{K}, \mathrm{P}_{\mathrm{i}}\right.$, sugars, free amino acids and $\mathrm{A}_{260}^{\circ}$ and $\mathrm{A}_{280}^{\mathrm{o}}$ absorbing materials) during imbibition were inversely related to seed weight. It is suggesting that interferences existed during seed development or deterioration had occurred in the low weight seed.

It can be noticed that seed quality of bean significantly affected field performance of bean plants and resulted in an increase of the studied plant growth traits (plant height, No. of leaves, No. of branches, leaf area leaf ${ }^{-1}$, leaf area plant ${ }^{-1}$, fresh and dry weights of leaves plant ${ }^{-1}$, fresh and dry weights of branches plant $^{-1}$, and total fresh and dry weights of shoot plant $^{-1}$ ) with increasing the level of seed quality class. It can be seen that there was a close relation between seed quality of bean and green pods yield and its components. In this respect, No. of green pods plant ${ }^{-1}$, weight of green pod, green pod yield plant $^{-1}$ and feddan ${ }^{-1}$ were increased as seed quality class was increased. It was found that bean dry seed yield and its components; empty and seeded pods plant $^{-1}$, total No. of pods plant ${ }^{-1}$, grades of dry seeded pods, No. of seeds plant ${ }^{-1}$, seed yield plant ${ }^{-1}$ and feddan ${ }^{-1}$ and seed index (100seed weight) was positively correlated with the class of sown seeds, the seeds which gave plants with high yield of dry seeds and its components were high in their quality and vice versa. It was shown that seed quality class markedly affected chemical constituents concentration of the different organs of bean plants

Fayoum J. Agric. Res. \& Dev., Vol. 20, No. 2, July, 2006 
produced from the different seed classes. In this respect, the high seed quality class significantly increased total sugars (total soluble carbohydrates in dry seeds), protein, N, P, K, Fe, Mn and Zn in leaves, green pods and dry seeds over that of light and ungraded seed classes.

Finally, in the light of the preceding results, it may be concluded that the results obtained suggest that the weight-seed separation of bean may enable for significantly improved germination and seedling growth. Also, high quality bean seeds to exhibit higher percent field performance and resulted in uniformity and establishment which reflected in high green pods and dry seed yield of bean either plant or feddan ${ }^{-1}$. Thus, it concluded that it is likely that farmers by sowing seeds of high seed quality, will obtain yield increases of bean (green pods and dry seed).

Key words: Bean, Seed quality, Germination, Growth, Yield, Chemical composition

\section{INTRODUCTION:}

Seed quality is one of the most important factors affecting the performance and productivity of most agricultural crops (Adul-Baki and Anderson, 1973; Brakke and Gardner, 1987 and Gadallah, 2000). Seeds of many horticultural crops have been separated by size, weight, density and colour (Smittle et al., 1976 and Smittle, 1982). Separation by seed weight offer a mean of improving germination, seedling growth for many crops. (Smith and Camper, 1975 and Smittle, 1982). Most research has indicated that the larger the seed, the better germination and subsequent rate of growth (Maranville and Clegg, 1977 and Qiu and Mosjidis, 1993). Research has emphasized the relationship of laboratory germination and seedling growth to seed quality (Brakke and Gardner, 1987 and Gadallah, 2000), but information relating seed quality to plant performance under field conditions is less available. Increased seed quality has been positively correlated with plant performance in the field (Burris et al., 1973). Production of a crop depends upon obtaining a timely stand of uniform, healthy, vigorous plants; seed quality is important in obtaining such stand (Maranville and Clegg, 1977). Although not all the responses are the same between crops, the balance of the evidence supports the use of the larger (heavier) seed within a given genotype (Burris et al., 1973).

However, because there is less information relating seed quality to other aspects of crop performance, possible direct effects of seed quality on plant development and yield are still difficult to discern. Undoubtedly, if seed quality affects yield, its influence should be discernible through some effects on plant growth processes.

Therefore, one of the basic problems confronting the seed industry is being able to separate the high quality seed within a given seed lot. Sufficient information is not available to accurately define the relationship of seed quality to the behavior of bean under field conditions.

Accordingly, the present study sought to determine whether seed quality (of several seed lots differing in seed weight) could be sued to improve germinability, growth and yield of bean.

Fayoum J. Agric. Res. \& Dev., Vol. 20, No. 2, July, 2006 
BEAN SEED QUALITY: ASSOCIATED GERMINABILITY 162 MATERIALS AND METHODS:

Experiments were conducted over 2 years of 2005 and 2006 in both laboratory and field, Fac. Agric., Fayoum Univ., Egypt. Seeds of bean (Phaseolus vulgaris L. cv. Giza 3) used in this study were produced by Ministry of Agriculture, Egypt. The original seed lot was manually separated into two weight classes identified: light and heavy. A portion of the original seed lot was retained to serve as ungraded class. The seed index (g $100^{-1}$ seeds) were determined for each seed class as a follows:

1- Light class (33.79-38.02g; in 2005 season) and (34.39-37.13g; in 2006 season).

2- Ungraded class (37.70-42.85g; in 2005 season) and (40.02- $49.81 \mathrm{~g}$; in 2006 season).

3- Heavy class (47.20-57.60g; in 2005 season) and (48.75-57.13g; in 2006 season).

On 28 February of each season, light, heavy and ungraded seeds were used in this study to determine the relationship between seed quality and germinability and field performance of bean. The seeds of each class with visibly damaged and immature seeds were removed.

\section{Laboratory study.}

Seed quality measurements.

For determination of germination\%, the suitable seeds (uniform and free from visible damage) were surface-disinfected for 30 seconds in $0.3 \%$ Rizolex-T50 (0-2,6 -dichloro -4-methyl phenyl 0,0 -dimethyl phosphorothioate) solution (w/v), then washed thoroughly with distilled water. Four hundred seeds in eight replicates for each weight class were allowed to germinate using paper rolls method as described by the International Rules for Seed Testing (ISTA, 1966) in a darkened incubator at a constant temperature of $20^{\circ} \mathrm{C}$. The replicates from each class, were arranged in a complete randomized design. Germination \% was monitored at $24 \mathrm{~h}$ interval for $144 \mathrm{~h}$ after sowing. Visible radicle protrusion was considered as a criterion for germination.

Quality index (QI) was carried out according the rules of ISTA (1966). This index provides information about the distribution of germination events over time.

Vigor index (VI) for each class was established by multiplying germination \% by length of the hypocotyl plus radicle at the end of germination period (144h) as mentioned by Abdul-Baki and Anderson (1973). This index was used as an indicator for providing information about the strength of seedling growth.

Seedling growth measurements.

Seedling growth measurements were recorded after 48, 72, 96, 120 and $144 \mathrm{~h}$ from sowing. Ten seedlings replicate ${ }^{-1}$ were used for each class. At each time of the sampling, seedlings were separated into embryonic axes and cotyledons. The following measurements were carried out:

Length of seedling, ten embryonic axes were taken from each replicate for each class to determine their mean length after 48, 72, 96, 120 and $144 \mathrm{~h}$ of germination. The length of both radicle and hypocotyl were also individually recorded for the 144 old seedlings.

Fresh and dry weights, fresh and dry weights of thirty embryonic axes of germinated seeds were recorded (immediately after sampling) from

Fayoum J. Agric. Res. \& Dev., Vol. 20, No. 2, July, 2006 
each replicate for each class. Fresh weights were determined immediately after sampling. These materials were dried at $70^{\circ} \mathrm{C}$ till constant weights were attained, then dry weight was obtained. The fresh and dry weights of both radicle and hypocotyl were also individually recorded for the seedlings after $144 \mathrm{~h}$. The dry material was ground in a mill for chemical analysis.

Water uptake and solute leakage measurements.

One hundred of uniform seeds and free from visible damage from each class were selected. The seeds were soaked in $100 \mathrm{ml}$ of distilled water in a $250 \mathrm{ml}$ beaker and allowed to leak for $8 \mathrm{~h}$ at constant temperature of $20^{\circ} \mathrm{C}$. Temperature was maintained during imbibitional period by immersing beakers with seeds into a thermo-regulated water bath. The experimental layout was complete randomized design with five replicates. Samples for water uptake and leakage analysis were taken at $1 \mathrm{~h}$ interval up to $8 \mathrm{~h}$ to quantity the rate of both water entry and solute efflux from seeds during imbibition. At each time of sampling (1h), the steep water was decanted from the seeds for analysis and the seeds were quickly blotted dry on filter paper and weighed to determine water uptake (as a percentage increase in initial fresh weight).

Also, electrical conductivity (EC) of the leakage was estimated $\left(\mathrm{dSm}^{-}\right.$ ${ }^{1} 100^{-1}$ seeds) using a conductometer model LF-91 (Eijkelkamp Co., The

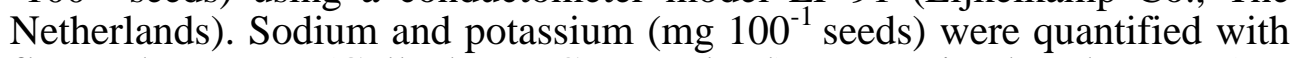
flame photometer (Gallenkamp Co., England). Inorganic phosphate, $\mathrm{P}_{\mathrm{i}}(\mathrm{mg}$ $100^{-1}$ seeds) was determined according to Chen et al., (1956). Total nitrogen (mg $100^{-1}$ seeds) was measured by micro-kjeldahl procedure (AOAC, 1990). Free amino acids $\left(\mathrm{mg}^{100^{-1}}\right.$ seeds) were quantified with ninhydrin method (Rosein, 1957), using glycine as a standard. Total sugars (mg $100^{-1}$ seeds) were estimated according to phenol-sulphoric technique (Dubois et al., 1956), using glucose as a standard. Measurements of leakage absorbing UV light at $\mathrm{A}^{\circ} 260$ and $\mathrm{A}^{\circ} 280$ due to protein and nucleic acids were estimated (Duke et al., 1983).

\section{Field study.}

Before sowing of bean seeds, soil samples $(0-30 \mathrm{~cm} /$ depth $)$ were taken each year and analyzed according to published procedure (Black, 1965). Soil analysis results in 2005 and 2006 are shown in Table (1).

Fayoum J. Agric. Res. \& Dev., Vol. 20, No. 2, July, 2006 
BEAN SEED QUALITY: ASSOCIATED GERMINABILITY

Table (1): Physical and chemical properties of the selected soil before sowing in both seasons

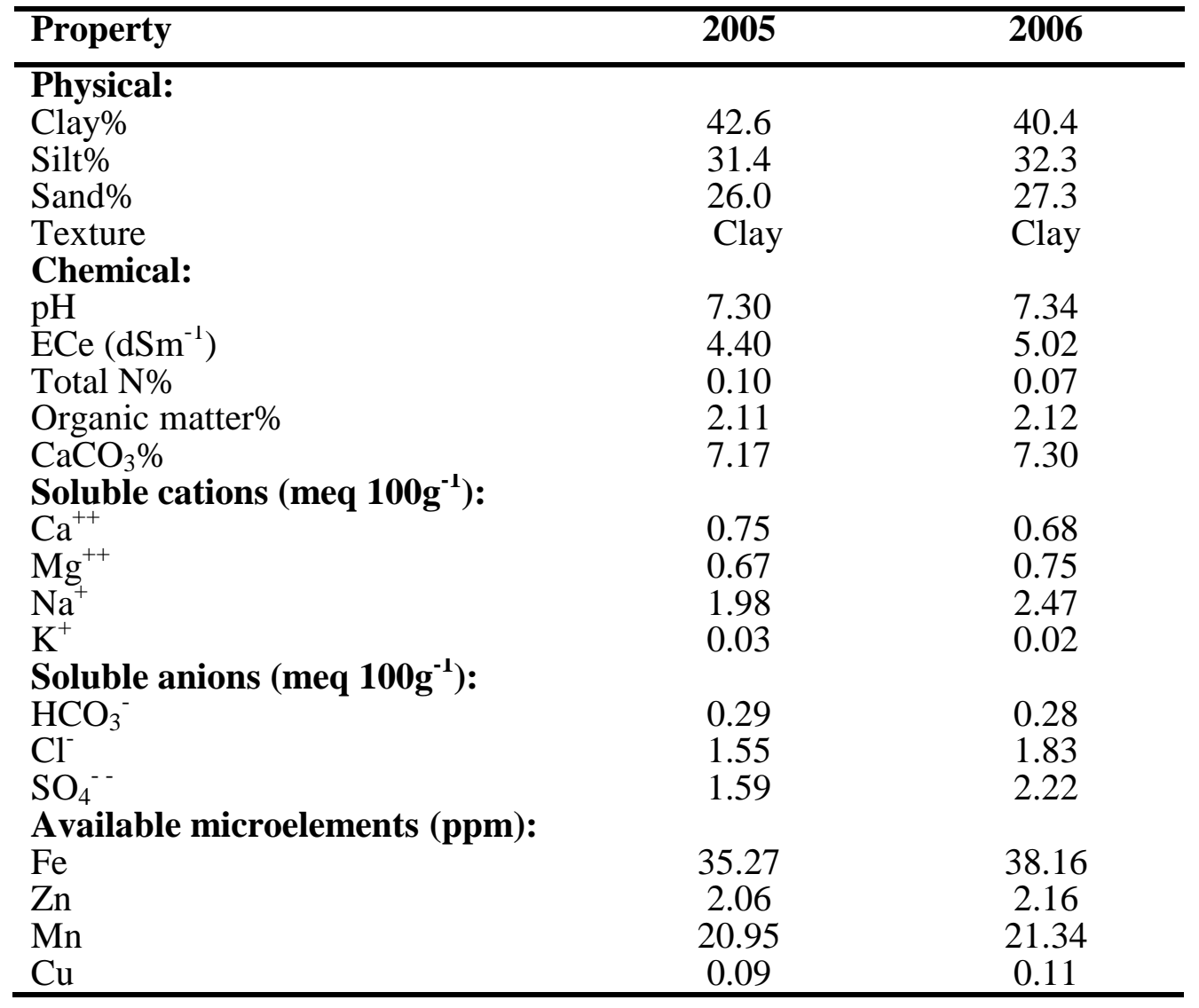

Plots were arranged in a randomized complete block design, replicated 3 times. Each plot consisted of 6 rows; $5 \mathrm{~m}$ long and $70 \mathrm{~cm}$ a part, within row spacing was $10 \mathrm{~cm}$. Seeds of each class were hand sown in the field on the $28^{\text {th }}$ February in both 2005 and 2006 seasons. Plots were seeded in excess and after emergence; plants were thinned to the desired stand (300 plants plot $^{-1}$ ). All other cultural practices for growing bean were applied according to those recommended by the Ministry of Agriculture, Egypt.

Plant Sampling.

At flowering, 10 plants randomly chosen from each replicate for each class were carefully cut off at the ground level and the following parameters were recorded: plant height $(\mathrm{cm})$, No. of leaves and branches plant $^{-1}$, fresh and dry weights of leaves and branches plant ${ }^{-1}(\mathrm{~g})$, total fresh and dry weights of shoot plant ${ }^{-1}$ (without root), leaf area leaf ${ }^{-1}\left(\mathrm{~cm}^{2}\right.$, using a digital leaf meter, Planimeter Lincolin, L1-3000 portable area Meter produced by L1-COR, Nebraska, USA) and leaf area plant ${ }^{-1}\left(\mathrm{~cm}^{2}\right)$. At 60 days from sowing (maturity of green pods); yield and its components were recorded from the whole two middle rows (throughout 21 days at 7 days interval) and the following measurements were recorded: No. of green pods plant $^{-1}$, fresh and dry weights pod ${ }^{-1}$, fresh and dry weights of pods plant ${ }^{-1}(\mathrm{~g})$ and green pods yield feddan ${ }^{-1}$ (ton). In each plot, plants of the 5 and 6 rows

Fayoum J. Agric. Res. \& Dev., Vol. 20, No. 2, July, 2006 
were left growing till pods approached the dry stage (90 days from sowing). The dry pods of twenty plants of each row picked and divided into two batches, empty and seeded pods. Total number and weight of empty and seeded pods were recorded. Seeded pods were sorted into 5 various grades: grade (A)-pods containing 1 seed pod ${ }^{-1}$, grade (B)-pods containing 2 seeds pod $^{-1}$, grade $(\mathbf{C})$-pods containing 3 seeds pod ${ }^{-1}$, grade (D)-pods containing 4 seeds pod $^{-1}$ and grade $(\mathbf{E})$-pods containing 5 seeds pod $^{-1}$. Number and weight of pods in each of the previous grades was counted and the seeds were handy obtained. Dry seeds weight plant ${ }^{-1}(\mathrm{~g})$, seed yield feddan ${ }^{-1}(\mathrm{~kg})$, seed index (100-seed weight, $\mathrm{g})$ were determined from air-dried seeds which contained approximately $10 \%$ moisture.

\section{Chemical analysis.}

In both seasons; at flowering stage, samples of fresh and dried leaves as well as fresh and dried green pods of 60 days old plants and powdered dry seeds (at harvesting time) were used for determining the following chemical constituents (the samples were dried in electric oven at $70^{\circ} \mathrm{C}$ till constant weight, then well ground for chemical analysis). In fresh leaves, leaf pigments; chlorophyll $\mathrm{a}, \mathrm{b}$ and total and carotenoids $\left(\mathrm{mg} \mathrm{g}^{-1}\right.$ fresh weight of leaf) were estimated. They extracted by acetone $80 \%$ then determined using colorimetric method as described by Arnon (1949). In dried leaves, the following parameters were determined: $\mathrm{N} \%$ was colorimetrically determined by using orange $\mathrm{G}$ dye according to the method of Hafez and Mikkelsen (1981). For P, K, Fe, Mn and $\mathrm{Zn}$ determination, the wet digestion of $0.1 \mathrm{~g}$ of ground dry material of leaves of each class was done with sulphoric and perchloric acids as described by Piper (1947). $\mathrm{P}\left(\mathrm{mg} 100^{-1} \mathrm{~g}\right.$ dry matter) was colorimetrically estimated by using chlorostannous molybdophosphoric blue colour method in sulphoric acid system as described by Jackson (1967). K (mg $100^{-1} \mathrm{~g}$ dry matter) was determined using a Perkin-Elmer, Flame-photometer (Page et al., 1982). Fe, $\mathrm{Mn}$ and $\mathrm{Zn}$ concentrations (mg $100^{-1} \mathrm{~g}$ dry matter) were determined using a Perkin-Elmer, Model 3300, Atomic Absorption spectrophotometer according to the method described by Champman and Pratt (1961). In green pods and dried seeds, N, P, K, Fe, Mn and Zn concentrations were determined using the same analytical methods as mentioned before. In addition, total sugars (in ethanolic extract, $80 \%$ of leaves and green pods) and total soluble carbohydrates\% (in digestive dry matter with sulphoric acid; $0.1 \mathrm{~N}$ of dry seeds) were colorimetrically determined using phenolsulphoric acid reagent method as outlined by Dubois $\boldsymbol{e t}$ al. (1956) as well as protein $\%$ were estimated by multiplying seed or green pod $\mathrm{N} \%$ by a factor of 6.25 for conversion of N\% to protein\% (Kelley and Bliss, 1975).

\section{Statistical analysis.}

According to the experimental design used (a randomized complete design for laboratory study and a randomized complete blocks design for field study), appropriate analysis of variance on the obtained results were achieved (Snedecor and Cochran, 1980). The least significant difference test (LSD) at 0.05 level was used to verity the difference between treatments mean.

Fayoum J. Agric. Res. \& Dev., Vol. 20, No. 2, July, 2006 


\section{RESULTS AND DISCUSSION: \\ I. Laboratory study.}

Seed index. Seed index was significantly varied among the seed classes of bean (Table 2). The heavy class seeds was the best whereas the light class seeds was the worst. Thus, a manual separation of bean seeds has strong effect on seed index.

Germination\%. Data in Table (2) show that germination\% increased gradually as germination proceeded for different seed classes of bean. Germination\% significantly differed among seed classes. It is also clear that during germination period, the highest percentage of germination was recorded by the heavy seeds class as compared to that of light and ungraded classes, which showed an increases in the germination $\%$ by $76.19 \%, 77.78 \%, 47.41 \%, 12.82 \%$ and $17.72 \%$ above that of light seeds class and by $27.59 \%, 15.66 \%, 9.62 \%, 8.64 \%$ and $9.41 \%$ above that of ungraded seeds class after 48, 72, 96, 120 and 144h of germination in the first season, respectively. In the second season, the increases were: $117.65 \%, 168.83 \%, 35.51 \%, 25.36 \%$ and $22.93 \%$ above that of light seeds class and by $21.31 \%, 27.78 \%, 5.06 \%, 5.41 \%$ and $13.20 \%$ above that of ungraded seeds class after 48,72, 96, 120 and $144 \mathrm{~h}$ of germination, respectively. These data strongly suggest that separation of bean seed by weight is desirable for maximizing germination. This result may be due to that nutrient reserves are greater for the heaviest seed and would support germination to better extent. In this respect, heavy seed showed a high germination $\%$ and early vigorous seedling growth as compared with light seeds (Gray and Steckel, 1986; Naylor, 1993 and Bredemeier et al., 2001). The obtained results are in agreement with those of King and Lamkin (1979); Qiu and Mosjidis (1993) and Gadallah (2000).

Quality and Vigor indices.

Quality index (QI) and vigor index (VI) were higher for heavy seeds class than the others (Table 2). At the end of germination period $144 \mathrm{~h}$, the QI of heavy seeds increased over the light and ungraded ones by $38.13 \%$ and $11.20 \%$ respectively, in the first season while in the second one, the increases were: $52.43 \%$ and $12.74 \%$, respectively. Data in Table (2) also indicate that, heavy seeds recorded significant increases in VI as compared to that of light and ungraded ones. The increases reached: $216.46 \%$ and $93.16 \%$ in the first season, respectively, while in the second one, the increases were: $197.83 \%$ and $78.60 \%$, respectively. This means that the heavy seeds of bean are considered the best quality seed lot, while the light seeds are considered the worst one. Thus, the reduction of vigor in light seeds (as expressed by quality and vigor indices) may be associated with decline in respiration and synthesis of proteins and carbohydrates (AbdulBaki and Anderson, 1973).

Radicle length, hypocotyl length and fresh and dry weights of embryonic axes.

The effects of different seed weight classes on a radicle length, hypocotyl length as well as fresh and dry weights of embryonic axes of bean seedlings were significant (Table 3). At any seed class, increasing the germination period from 72 to $144 \mathrm{~h}$, were associated with progressive increases in the length of radicle. It is obvious that, decreasing the seed weight class was accompanied with reductions in length of radicle and

Fayoum J. Agric. Res. \& Dev., Vol. 20, No. 2, July, 2006 
hypocotyl as well (after 144h of germination) fresh and dry weight. These unsatisfactory results of light seed class may be related to loss of vigor and perhaps undesirable metabolic changes in their axes, which was considered the site of vigor, had occurred (Abdul-Baki and Anderson, 1973). A similar result had been found by Sayed et al. (1990) and Gadallah (2000).

Table (2): Seed index, germination\%, quality index (QI) and vigor index (VI) of bean seeds as affected by seed quality class in both seasons

\begin{tabular}{|c|c|c|c|c|c|c|c|c|}
\hline \multirow{3}{*}{ Seed class } & \multirow{3}{*}{ Seed index } & \multicolumn{7}{|c|}{ Germination time (h) } \\
\hline & & \multicolumn{5}{|c|}{ Germination \% } & QI & VI \\
\hline & & 48 & 72 & 96 & 120 & 144 & \multicolumn{2}{|c|}{144} \\
\hline \multicolumn{9}{|c|}{ 1 $^{\text {st }}$ season } \\
\hline Light & $33.79-38.02$ & 10.50 & 27.00 & 58.00 & 78.00 & 79.00 & 57.52 & 274.75 \\
\hline Ungraded & $37.70-42.85$ & 14.50 & 41.50 & 78.00 & 81.00 & 85.00 & 71.45 & 450.12 \\
\hline Heavy & $47.20-57.60$ & 18.50 & 48.00 & 85.50 & 88.00 & 93.00 & 79.45 & 869.47 \\
\hline $\operatorname{LSD}_{(0.05)}$ & & 3.11 & 5.02 & 5.71 & 2.92 & 4.07 & 6.44 & 68.14 \\
\hline \multicolumn{9}{|c|}{$2^{\text {nd }}$ season } \\
\hline Light & $34.39-37.13$ & 8.50 & 19.25 & 61.25 & 70.00 & 78.50 & 53.06 & 277.29 \\
\hline Ungraded & $40.02-49.81$ & 15.25 & 40.50 & 79.00 & 83.25 & 85.25 & 71.74 & 462.40 \\
\hline Heavy & $48.75-57.13$ & 18.50 & 51.75 & 83.00 & 87.75 & 96.50 & 80.88 & 825.84 \\
\hline $\operatorname{LSD}_{(0.05)}$ & & 2.72 & 4.32 & 2.81 & 3.09 & 5.31 & 7.19 & 58.42 \\
\hline
\end{tabular}

Table (3): Radical length (cm), hypocotyl length (cm) and embryonic axes fresh and dry weights $\left({\mathrm{g} 10^{-1}}^{-1}\right.$ axes) of bean seedling as affected by seed quality class in both seasons

\begin{tabular}{|c|c|c|c|c|c|c|c|}
\hline \multirow{4}{*}{ Seed class } & \multicolumn{7}{|c|}{ Germination time (h) } \\
\hline & \multirow{2}{*}{\multicolumn{4}{|c|}{$\begin{array}{l}\text { Radical length } \\
(\mathbf{c m})\end{array}$}} & \multirow{3}{*}{$\begin{array}{c}\text { Hypocotyl } \\
\text { length }(\mathrm{cm})\end{array}$} & \multicolumn{2}{|c|}{ Embryonic axes } \\
\hline & & & & & & $\begin{array}{c}\text { Fresh } \\
\text { weight }(\mathrm{g})\end{array}$ & $\begin{array}{c}\text { Dry weight } \\
\text { (g) }\end{array}$ \\
\hline & 72 & 96 & 120 & 144 & & & 44 \\
\hline \multicolumn{8}{|c|}{$1^{\text {st }}$ season } \\
\hline Light & 1.10 & 3.40 & 5.42 & 8.88 & 3.50 & 7.92 & 0.75 \\
\hline Ungraded & 1.30 & 4.88 & 6.28 & 10.28 & 5.28 & 9.51 & 2.44 \\
\hline Heavy & 1.88 & 5.75 & 8.68 & 14.57 & 9.01 & 10.39 & 3.15 \\
\hline $\mathbf{L S D}_{(0.05)}$ & 0.11 & 0.60 & 0.61 & 1.08 & 1.12 & 0.80 & 0.62 \\
\hline \multicolumn{8}{|c|}{$2^{\text {nd }}$ season } \\
\hline Light & 1.31 & 2.80 & 4.83 & 7.68 & 3.51 & 9.90 & 1.00 \\
\hline Ungraded & 1.45 & 4.94 & 6.68 & 10.56 & 5.44 & 11.88 & 3.05 \\
\hline Heavy & 1.94 & 6.08 & 8.18 & 13.29 & 8.88 & 12.99 & 3.89 \\
\hline $\operatorname{LSD}_{(0.05)}$ & 0.39 & 0.69 & 1.19 & 1.83 & 0.94 & 0.59 & 0.47 \\
\hline
\end{tabular}

\section{Water uptake.}

Table (4) clearly show that, an increase in water uptake was observed during all the time of imbibition (up 8h) for the seeds of the different seed weight classes, although differential rates of water uptake had developed in response to the seed weight class. It is evident that decrease in seed weight caused a significant decrease in water uptake of seeds. These results can be explained on the basis that deteriorative changes in membrane systems of the low seed weight class may have occurred. In this respect, Krieg and Bartee (1974) mentioned that, low seed weight class absorbed relatively less water than those of high ones.

Fayoum J. Agric. Res. \& Dev., Vol. 20, No. 2, July, 2006 
BEAN SEED QUALITY: ASSOCIATED GERMINABILITY 168

Table (4): Water uptake\% of the initial bean seed fresh weight as affected by seed quality class in both seasons

\begin{tabular}{|l|c|c|c|c|c|c|c|c|c|}
\hline \multirow{2}{*}{ Seed class } & \multicolumn{8}{|c|}{ Imbibition time (h) } \\
\cline { 2 - 10 } & $\mathbf{1}$ & $\mathbf{2}$ & $\mathbf{3}$ & $\mathbf{4}$ & $\mathbf{5}$ & $\mathbf{6}$ & $\mathbf{7}$ & $\mathbf{8}$ \\
\hline \multicolumn{8}{|c|}{ season } \\
\hline Light & 21.72 & 39.87 & 56.58 & 72.27 & 84.95 & 87.04 & 92.82 & 105.87 \\
\hline Ungraded & 29.00 & 43.30 & 67.14 & 81.65 & 89.32 & 90.20 & 108.37 & 121.34 \\
\hline Heavy & 38.95 & 50.20 & 77.49 & 83.32 & 97.20 & 108.54 & 127.88 & 147.48 \\
\hline LSD $_{(\mathbf{0 . 0 5})}$ & $\mathbf{5 . 1 7}$ & $\mathbf{3 . 0 3}$ & $\mathbf{7 . 8 9}$ & $\mathbf{1 . 7 2}$ & $\mathbf{3 . 3 7}$ & $\mathbf{1 . 3 1}$ & $\mathbf{1 3 . 0 1}$ & $\mathbf{1 1 . 1 0}$ \\
\hline \multicolumn{8}{|c|}{$\mathbf{2}^{\text {nd }}$ season } \\
\hline Light & 20.95 & 37.57 & 58.09 & 72.18 & 83.90 & 86.00 & 93.88 & 104.82 \\
\hline Ungraded & 29.78 & 46.11 & 67.10 & 78.77 & 89.61 & 90.19 & 108.27 & 134.41 \\
\hline Heavy & 36.11 & 50.49 & 78.77 & 81.65 & 95.13 & 114.81 & 131.01 & 150.57 \\
\hline LSD $_{(\mathbf{0 . 0 5})}$ & $\mathbf{5 . 1 3}$ & $\mathbf{3 . 3 7}$ & $\mathbf{6 . 1 8}$ & $\mathbf{4 . 0 1}$ & $\mathbf{3 . 1 0}$ & $\mathbf{2 . 7 1}$ & $\mathbf{8 . 1 9}$ & $\mathbf{1 3 . 1 7}$ \\
\hline
\end{tabular}

\section{Conductivity of electrolyte leakage.}

Data in Table (5) exhibited that conductivity of electrolytes leakage was significantly and inversely correlated with the seed weight class. In addition, loss of electrolytes from all seed weight classes increased with increasing imbibition time up to $8 \mathrm{~h}$. Increasing leakage of light seed weight class may be attributed to enhancement of permeability of cell membrane. It is interesting to note that, the electrical conductivity of electrolyte leakage from seeds was negatively correlated with their vigor, since, the seeds which gave high conductivity were low in vigor and vice versa. Similar results were documented by Bartee and Krieg (1974) and Gadallah (2000).

Table (5): Conductivity of electrolytes leakage $\left(\mathrm{EC}, \mathrm{dSm}^{-1} \mathbf{1 0 0}^{-1}\right.$ seeds) from imbibition bean seeds as affected by seed quality class in both seasons

\begin{tabular}{|c|c|c|c|c|c|c|c|c|}
\hline \multirow{3}{*}{ Seed class } & \multicolumn{8}{|c|}{ Imbibition time (h) } \\
\hline & \multicolumn{8}{|c|}{ EC $\left(\mathrm{dsm}^{-1} 100^{-1}\right.$ seeds $)$} \\
\hline & 1 & 2 & 3 & 4 & 5 & 6 & 7 & 8 \\
\hline \multicolumn{9}{|c|}{$1^{\text {st }}$ season } \\
\hline Light & 0.328 & 0.560 & 0.640 & 0.830 & 1.050 & 1.125 & 1.300 & 1.361 \\
\hline Ungraded & 0.275 & 0.330 & 0.575 & 0.675 & 1.125 & 1.263 & 1.331 & 1.392 \\
\hline Heavy & 0.205 & 0.363 & 0.405 & 0.775 & 0.830 & 0.940 & 1.000 & 1.050 \\
\hline $\mathbf{L S D}_{(0.05)}$ & 0.061 & 0.021 & 0.127 & 0.087 & 0.189 & 0.108 & 0.022 & 0.020 \\
\hline \multicolumn{9}{|c|}{$2^{\text {nd }}$ season } \\
\hline Light & 0.275 & 0.540 & 0.645 & 0.900 & 1.111 & 1.200 & 1.275 & 1.370 \\
\hline Ungraded & 0.322 & 0.575 & 0.675 & 0.872 & 1.063 & 1.103 & 1.200 & 1.300 \\
\hline Heavy & 0.210 & 0.384 & 0.452 & 0.753 & 0.813 & 0.908 & 0.985 & 1.022 \\
\hline $\operatorname{LSD}_{(0.05)}$ & $\mathbf{0 . 0 3 8}$ & 0.027 & 0.029 & 0.022 & 0.039 & 0.078 & 0.061 & 0.053 \\
\hline
\end{tabular}

\section{Leakage of inorganic solutes.}

The influence of seed weight class on inorganic leaked solutes of sodium $(\mathrm{Na})$, potassium $(\mathrm{K})$ and inorganic phosphorus $\left(\mathrm{P}_{\mathrm{i}}\right)$ was significant during all times of imbibition period of the three tested seed classes; light, ungraded and heavy (Table 6). Light seed weight class, gave the greatest amounts of inorganic solutes; $\mathrm{Na}, \mathrm{K}$ and $\mathrm{P}_{\mathrm{i}}$ while, the heavy seed class attained the least one. Moreover, progressive increases in inorganic leaked solutes of $\mathrm{Na}, \mathrm{K}$ and $\mathrm{P}_{\mathrm{i}}$ was recorded as the imbibition increased up to $8 \mathrm{~h}$.

Fayoum J. Agric. Res. \& Dev., Vol. 20, No. 2, July, 2006 
The increased leakage of inorganic solutes with decreasing seed weight class suggests a cellular degradation or increased membrane permeability allowing for rapid efflux the soluble $\mathrm{Na}, \mathrm{K}$ and $\mathrm{P}_{\mathrm{i}}$ salts.

\section{Leakage of organic solutes.}

Relative leakage of organic solutes; free amino acids, sugar, and $\mathrm{A}^{\mathrm{0}} 260$ and $\mathrm{A}^{\mathrm{0}} 280$ absorbing materials (esp. proteins and nucleic acids) from the different seed classes is shown in Tables $(7 \& 8)$. The results indicate that the leakage of organic solutes were significantly influenced with seed weight class during all times of imbibition for the tested seed classes (light, ungraded and heavy). It was obvious that leakage of amino acids and sugars were inversely proportional to seed weight class indicating that the lower the seed weight class, the higher the leakage of the free amino acids and sugars. This result may be as a result of membrane dysfunction with decreasing in seed density class (Krieg and Bratte, 1974). Measurements of $\mathrm{A}^{\circ} 260$ and $\mathrm{A}^{\mathrm{O}} 280$ absorbing materials (esp. proteins nucleic acids) in the imbibiting medium (Table 8), show that these was a linear rate of loss occurred throughout the period of imbibition for all seed classes. The light seeds showing much greater rate of leakage than the other two classes, heavy and ungraded. These results are in accordance with those of Gadallah (2000).

Collectively, these results indicate that the quantity of material available for leaching from the seed was significantly influenced by seed weight. Seed coat and cellular integrity are apparently much less in the low weight (light) seed compared with the higher weight seed (heavy). Thus, the high quantity of soluble compounds leaked from the low weight seeds should provide an ideal media for a rapid growth microorganism.

\section{Field study.}

Vegetative growth.

Data represented in Table (9) indicate that, all growth characters; plant height, No. of leaves plant ${ }^{-1}$, leaf area leaf ${ }^{-1}$, leaf area plant ${ }^{-1}$ and No. of branches plant ${ }^{-1}$ recorded a gradual increase as a result of seed weight increase in both seasons. This increase in these characters from all seed weight classes significantly differed. In this respect, values of plant growth (plant height, No. of leaves plant ${ }^{-1}$, leaf area leaf ${ }^{-1}$, leaf area plant ${ }^{-1}$ and No. of branches plant ${ }^{-1}$ ) produced from heavy seed class were significantly higher than those of the other two seed weight classes (light and ungraded) in both seasons. In the first season, the increases which recorded by heavy seed class as compared to those of light and ungraded ones reached: $48.60 \%$ and $27.26 \%, 22.43 \%$ and $13.77 \%, 34.65 \%$ and $18.63 \%, 64.85 \%$ and $34.97 \%$ as well as $50.00 \%$ and $24.14 \%$, respectively. In the second one, the increases were: $30.81 \%$ and $15.94 \%, 17.16 \%$ and $2.83 \%, 27.04 \%$ and

Fayoum J. Agric. Res. \& Dev., Vol. 20, No. 2, July, 2006 
Table 6, 7

Fayoum J. Agric. Res. \& Dev., Vol. 20, No. 2, July, 2006 
Table 8

Fayoum J. Agric. Res. \& Dev., Vol. 20, No. 2, July, 2006 
BEAN SEED QUALITY: ASSOCIATED GERMINABILITY

$8.80 \%, 51.46 \%$ and $20.89 \%$ as well as $35.04 \%$ and $27.59 \%$ for plant height, No. of leaves plant ${ }^{-1}$, leaf area leaf ${ }^{-1}$, leaf area plant ${ }^{-1}$ and No. of branches plant $^{-1}$, respectively. Data shown in Table (10) represented the response of fresh and dry weights of leaves plant ${ }^{-1}$, fresh and dry weights of branches plant $^{-1}$ as well as fresh and dry weights of shoot plant ${ }^{-1}$ to the three different seed classes used. It could be observed that the previous characters were significantly influenced by seed quality, in both seasons representing their highest values with heavy class of seed. By other means, heavy seed class recorded an increase in the first season: $43.59 \%$ and $18.65 \%, 75.31 \%$ and $12.02 \%, 58.2 \%$ and $22.98 \%, 56.03 \%$ and $23.13 \%, 47.64 \%$ and $19.89 \%$ as well as $69.43 \%$ and $15.59 \%$ when compared with the light and ungraded class, respectively. In the second one, the increases reached: $39.87 \%$ and $12.33 \%, 69.03 \%$ and $27.61 \%, 39.85 \%$ and $17.59 \%, 39.86 \%$ and $8.50 \%$ as well as $59.11 \%$ and $21.66 \%$. For fresh and dry weights of leaves plant ${ }^{-1}$, fresh and dry weights of branches plant ${ }^{-1}$ and fresh and dry weights of shoot plant $^{-1}$, respectively. It means that the best plant growth was associated with the heaviest seed class. On the contrary, the poorest growth was recorded with light seed class. These findings were true in both seasons. Thus, the differences in initial seed weights among the density classes created a differential degree of growth among the classes of seed. However, these findings confirm that seed quality may affect plant fresh and dry weights during the first stages of development. Most plant tissues involved in the production of dry matter are formed after seedling emergence and it seems unlikely that seed quality would influence their ability to carry out physiological processes and accumulate dry matter during the whole vegetative of development. These informations confirmed the findings of Tekrony and Egli (1991); Perin et al. (2002) and Rodo and Marcos (2003).

Table (9): Plant height, No. of leaves plant $^{-1}$, leaf area leaf ${ }^{-1}$, leaf area plant $^{-1}$ and No. of branches plant ${ }^{-1}$ of bean as affected by seed quality in both seasons

\begin{tabular}{|c|c|c|c|c|c|}
\hline Seed class & $\begin{array}{c}\text { Plant } \\
\text { height } \\
\text { (cm) }\end{array}$ & $\begin{array}{c}\text { No. of leaves } \\
\text { plant }^{-1}\end{array}$ & $\begin{array}{c}\text { leaf area } \\
\text { leaf }^{-1}\left(\mathrm{~cm}^{2}\right)\end{array}$ & $\begin{array}{c}\text { leaf area } \\
\text { plant }^{-1} \\
\left(\mathrm{~cm}^{2}\right)\end{array}$ & $\begin{array}{c}\text { No. of } \\
\text { branches } \\
\text { plant }^{-1}\end{array}$ \\
\hline \multicolumn{6}{|c|}{$\mathbf{1}^{\mathrm{st}}$ season } \\
\hline Light & 25.35 & 14.71 & 88.90 & 1307.72 & 6.00 \\
\hline Ungraded & 29.60 & 15.83 & 100.90 & 1597.25 & 7.25 \\
\hline High & 37.67 & 18.01 & 119.70 & 2155.80 & 9.00 \\
\hline $\operatorname{LSD}_{(0.05)}$ & 3.71 & 0.82 & 8.37 & 113.15 & 0.96 \\
\hline \multicolumn{6}{|c|}{$2^{\text {nd }}$ season } \\
\hline Light & 24.08 & 14.93 & 89.50 & 1336.24 & 6.85 \\
\hline Ungraded & 27.17 & 16.02 & 104.50 & 1674.09 & 7.25 \\
\hline High & 31.50 & 17.80 & 113.70 & 2023.86 & 9.25 \\
\hline $\operatorname{LSD}_{(0.05)}$ & 2.82 & 0.79 & 7.82 & 121.09 & 0.33 \\
\hline
\end{tabular}

Fayoum J. Agric. Res. \& Dev., Vol. 20, No. 2, July, 2006 
Farouk M. Gadallah

Table (10): Fresh and dry weights of leaves plant ${ }^{-1}$, branches plant ${ }^{-1}$ and shoot Plant $^{-1}$ of bean as affected by seed quality of bean in both seasons

\begin{tabular}{|c|c|c|c|c|c|c|}
\hline \multirow[t]{2}{*}{ Seed class } & \multicolumn{2}{|c|}{$\begin{array}{l}\text { Leaves weight } \\
\text { plant }^{-1}(\mathrm{~g})\end{array}$} & \multicolumn{2}{|c|}{$\begin{array}{l}\text { Branches weight } \\
\text { plant }^{-1}(\mathrm{~g})\end{array}$} & \multicolumn{2}{|c|}{$\begin{array}{l}\text { Shoot weight plant }{ }^{-1} \\
\text { (Leaves \& branches, g }\end{array}$} \\
\hline & Fresh & Dry & Fresh & Dry & Fresh & Dry \\
\hline \multicolumn{7}{|c|}{$1^{\mathrm{st}}$ season } \\
\hline Light & 14.89 & 2.34 & 5.68 & 1.16 & 20.57 & 3.50 \\
\hline Ungraded & 18.02 & 3.66 & 7.31 & 1.47 & 25.33 & 5.13 \\
\hline High & 21.38 & 4.10 & 8.99 & 1.81 & 30.37 & 5.91 \\
\hline $\operatorname{LSD}_{(0.05)}$ & 2.02 & 0.87 & 090 & 026 & 3.92 & 065 \\
\hline \multicolumn{7}{|c|}{$2^{\text {nd }}$ season } \\
\hline Light & 15.50 & 2.68 & 6.50 & 1.38 & 22.00 & 4.06 \\
\hline Ungraded & 19.30 & 3.55 & 7.73 & 1.76 & 27.03 & 5.31 \\
\hline High & 21.68 & 4.53 & 9.09 & 1.93 & 30.77 & 6.46 \\
\hline $\mathbf{L S D}_{(0.05)}$ & 0.97 & 0.78 & 0.93 & 0.14 & 2.88 & 0.93 \\
\hline
\end{tabular}

Green pod yield and its components.

Data concerning No. of green pods plant ${ }^{-1}$, fresh and dry weights pod $^{-1}$, total green pods yield plant ${ }^{-1}$ and feddan ${ }^{-1}$ during both seasons as affected seed quality are presented in Table (11). It could be noticed that heavy seed class showed the highest values of the previous parameters as compared to light and ungraded classes is both seasons. On the other hand, the lowest values in this respect were associated with light seed class. However, the variation within the three classes of seed quality was significant for all criteria showed in Table (11). In this respect, it was also found that the superiority of heavy seed class over light and ungraded ones in the first season was: $29.83 \%$ and $14.85 \%, 26.06 \%$ and $11.68 \%, 34.55 \%$ and $8.83 \%, 63.66 \%$ and $28.26 \%$, and $63.59 \%$ and $28.39 \%$. In the second one the increases reached: $34.07 \%$ and $8.93 \%, 16.89 \%$ and $9.85 \%, 64.00 \%$ and $18.84 \%, 56.71 \%$ and $19.66 \%$ and $56.66 \%$ and $19.66 \%$ for No. of total green pods plant ${ }^{-1}$, fresh and dry weights pod ${ }^{-1}$, total green pods yield plant ${ }^{-1}$ and feddan ${ }^{-1}$, respectively. The superiority of heavy seed class for all characters showed in Table (11) was mainly due to the increase its vegetative growth than other classes, which means that heavy seed class resulted in a pronounced increase in the number of leaves, fresh and dry weight plant ${ }^{-1}, \ldots$...etc, consequently green pod yield and its components is expected to be higher for heavy seed class plants than others. However, green pod yield compensation in plots planted with heavy seed class may have been affected through the increased branching and pod set plant ${ }^{-1}$ and it has also been reported that plants grown from heavy seed class may have greater yielding capacity at uniform stands (Stivers and Sweeringin, 1978). Also, The number of green pods plant ${ }^{-1}$ increased with increasing seed weight of faba bean (Salih, 1983).

Fayoum J. Agric. Res. \& Dev., Vol. 20, No. 2, July, 2006 
BEAN SEED QUALITY: ASSOCIATED GERMINABILITY

Table (11): No. of green pods plant ${ }^{-1}$, fresh and dry weights green $\operatorname{pod}^{-1}$ and green pods plant ${ }^{-1}$ of bean as affected by seed quality in both seasons

\begin{tabular}{|c|c|c|c|c|c|c|}
\hline \multirow[t]{2}{*}{ Seed class } & \multirow{2}{*}{$\begin{array}{c}\text { No. of } \\
\text { green pods } \\
\text { plant }^{-1}\end{array}$} & \multicolumn{2}{|c|}{$\begin{array}{l}\text { Weight green } \\
\operatorname{pod}^{-1}(\mathrm{~g})\end{array}$} & \multicolumn{2}{|c|}{$\begin{array}{l}\text { Weight of green } \\
\text { pods plant }^{-1}(\mathrm{~g})\end{array}$} & \multirow{2}{*}{$\begin{array}{c}\text { Green pods } \\
\text { yield feddan' } \\
1 \text { (ton) }\end{array}$} \\
\hline & & Fresh & Dry & Fresh & Dry & \\
\hline \multicolumn{7}{|c|}{$1^{\text {st }}$ season } \\
\hline Light & 11.5 & 6.60 & 0.46 & 75.90 & 5.29 & 4.34 \\
\hline Ungraded & 13.0 & 7.45 & 0.68 & 96.85 & 8.84 & 5.53 \\
\hline High & 14.93 & 8.32 & 0.74 & 124.22 & 11.05 & 7.10 \\
\hline $\mathbf{L S D}_{(0.05)}$ & 1.61 & 070 & 0.04 & 6.13 & 2.25 & 1.09 \\
\hline \multicolumn{7}{|c|}{$2^{\text {nd }}$ season } \\
\hline Light & 13.0 & 6.87 & 0.50 & 89.31 & 6.50 & 5.10 \\
\hline Ungraded & 16.0 & 7.31 & 0.69 & 116.96 & 11.04 & 6.68 \\
\hline High & 17.43 & 8.03 & 0.82 & 139.96 & 14.29 & 7.99 \\
\hline $\operatorname{LSD}_{(0.05)}$ & 1.07 & 0.41 & $\mathbf{0 . 1 7}$ & 19.08 & 3.72 & 1.01 \\
\hline
\end{tabular}

Dry seed yield and its components.

Data showing the influence of seed quality on dry seed yield of bean and its components expressed as No. of seeded pods plant ${ }^{-1}$. No. of empty

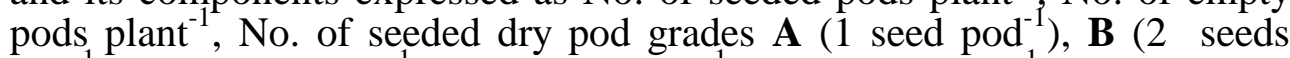
$\left.\operatorname{pod}^{-1}\right), \mathbf{C}\left(3\right.$ seeds $\left.^{-1}\right), \mathbf{D}\left(4\right.$ seeds pod $\left.^{-1}\right), \mathbf{F}\left(5\right.$ seeds pod $\left.^{-1}\right)$, total number of dry seeds plant ${ }^{-1}$, total dry seed yield plant ${ }^{-1}$ and feddan ${ }^{-1}$ and 100 -seed weight (seed index) are presented in Table (12).

Number of empty, seeded and total dry pods.

Data in Table (12) show that No. of empty, seeded and total dry bean pods significantly responded to the seed quality in both seasons. The comparison among the three investigated seed classes of bean within each aforementioned trait showed that the heavy seed class significantly resulted in less number of empty dry bean pods and more number of seeded and total dry bean pods than those achieved with other seed quality classes. In this respect, the decrease in No. of empty dry bean pods recorded by the heavy seed class as compared to the light and ungraded ones were: $39.34 \%$ and $15.91 \%$, respectively in the first season, while reached: $42.02 \%$ and $15.58 \%$, respectively in the second season. The increases in No. of seeded and total dry bean pods recorded by the heavy seed class as compared to the light and ungraded ones reached: $50.19 \%$ and $21.69 \%$, respectively in the first season while in the second one were: $64.96 \%$ and $30.05 \%$, respectively.

Number of seeded dry bean pod grades (A-E).

The results presented in Table (12) reflect the influence of seed quality on number seeded bean pod grades; A-E in both seasons. Comparisons between means of the three seed quality classes showed a significant difference in the No. of seeded dry bean pods grades; A-E and the trend was exactly the same in both seasons. In this respect, the heavy seed class significantly gave the greatest number of seeded dry bean pod grades (A-E) as compared to the other classes; light and ungraded ones. The corresponding increments in No. of seeded dry bean pods grades (A-E) by the heavy seed class over the light and ungraded ones were: $52.13 \%$ and

Fayoum J. Agric. Res. \& Dev., Vol. 20, No. 2, July, 2006 
Table 12

Fayoum J. Agric. Res. \& Dev., Vol. 20, No. 2, July, 2006 
BEAN SEED QUALITY: ASSOCIATED GERMINABILITY.

$16.26 \%, 20.36 \%$ and $10.33 \%, 68.07 \%$ and $16.96 \%, 35.47 \%$ and $10.84 \%$, as well as $36.04 \%$ and $29.06 \%$ in the first season and $99.25 \%$ and $18.67 \%$, $32.93 \%$ and $11.99 \%, 32.29 \%$ and $17.23 \%, 50.00 \%$ and $15.68 \%$ and $49.07 \%$ and $21.05 \%$, in the second season for grades of $\mathrm{A}, \mathrm{B}, \mathrm{C}, \mathrm{D}$ and $\mathrm{E}$ respectively.

No. of seeds plant ${ }^{-1}$, dry seed yield plant $^{-1}$ and feddan ${ }^{-1}$ and seed index.

The influence of seed quality class; light, ungraded and heavy on No. of seeds plant ${ }^{-1}$, seed yield plant ${ }^{-1}$ and feddan ${ }^{-1}$ and seed index in both seasons are shown in Table (12). Seed class differences in the previous mentioned characters were significant and the heavy seed class was superior to the other in this regards. Differences between the heavy seed class, light and ungraded classes were: $41.73 \%$ and $14.24 \%$ and $43.78 \%$ and $16.22 \%$, respectively for No. of seeds plant ${ }^{-1}, 86.16 \%$ and $30.95 \%$ and $88.39 \%$ and $31.13 \%$, for dry seed yield plant ${ }^{-1}$ as well as $86.86 \%$ and $30.79 \%, 88.19 \%$ and $31.05 \%$ for seed yield feddan ${ }^{-1}$ as well as $29.12 \%$ and $12.86 \%$ and $31.23 \%$ and $12.77 \%$ for seed index in the first and second seasons for light and ungraded classes, respectively. Thus, seed yield and its components was significantly correlated with planted seed quality. The advantage of graded seed might be explained by the theory of Fontes and Ohlrogge (1972) that ungraded soybeans may produce lower yields than graded seed because plants from large seed suppress plants from small seeds. Generally, crop yield is the product of the interaction of a large number of genetically controlled physiological processes and morphological components that evolved in sequential developmental patterns (Al-Mukhtar and Coyne, 1981). It is well Known that enhanced seed quality results in improved field emergence which often leads to increased yield (Johnson and Mulvaney, 1980). Fernandez and Miller (1985) and Westermann and Crothers (1977) mentioned that seed yield in legumes was determined by 3 major yield components, i.e. pods plant ${ }^{-1}$, seeds pod ${ }^{-1}$ and seed weight. The highest seed yield was obtained when all were maximized. In addition, the increasing seed weight led to increase in seed yield and 1000-seed weight of pea (Ondrej, 1984), seed yield plant ${ }^{-1}$, weight and No. of seeds pod $^{-1}$ of cowpea (Yadava, 1990), seed yield of bean (Das and Chatterjee, 1992) and seed yield of soybean (Zaimoglu et al., 2004). Hence an increase in seed yield must be accompanied by an increase in at least one of these components. However, because these components were interrelated and both physiological and morphological aspects of plant growth and development were believed to influence these components, an increase in one might always result in increased yield. Thus, the current results confirm the above mentioned findings. These findings, generally, indicated that the heavy seed class was favourable and resulted in the best performance in this regards.

\section{Chemical constituents.}

\section{In leaves.}

Changes in some chemical constituents; leaf pigments (chlorophyll $\mathrm{a}, \mathrm{b}$ and total as well as carotenoids), total sugars (TS), protein, macronutrients (N, P and $\mathrm{K}$ ) and micro-nutrients (Fe, Mn and $\mathrm{Zn}$ ) in leaves of plants produced from the different seed quality classes are shown in Tables (13\&14). Under different seed quality classes, increasing seed weight resulted in a gradual increase in the values of chemical constituents. The

Fayoum J. Agric. Res. \& Dev., Vol. 20, No. 2, July, 2006 
highest values of those constituents were recorded with the plants of heavy seed class. Whereas, the lowest values resulted from plants of light seed class. However, the variation within the three seed quality classes was significant for all chemical constituents showed in Tables (13\&14). In this regard, the increases which recorded by the heavy seed class over the light and ungraded ones reached: $142.73 \%$ and $35.88 \%, 132.25 \%$ and $29.41 \%$, $98.03 \%$ and $15.17 \%$ and $77.60 \%$ and $21.79 \%$ in the first season for chlorophyll a, b and total as well as carotenoids, respectively while, in the second one the increases were: $134.32 \%$ and $23.68 \%, 108.11 \%$ and $11.29 \%$, $116.93 \%$ and $17.61 \%$ and $75.00 \%$ and $24.44 \%$, for the above mentioned parameters as stated before. In a like manner, the highest values of TS, protein, $\mathrm{N}, \mathrm{P}, \mathrm{K}, \mathrm{Fe}, \mathrm{Mn}$ and $\mathrm{Zn}$ concentrations in leaves of bean were detected with plants produced from the heavy seed class in both seasons than those of other two classes; light and ungraded (Table 14). In this respect, the differences between the three seed classes were statistically significant in both seasons. The corresponding increase in the above mentioned chemical constituents by the heavy seed class over the light and ungraded ones were: $34.34 \%$ and $21.09 \%$ in TS, $35.66 \%$ and $11.82 \%$ in protein, $35.68 \%$ and $11.58 \%$ in $\mathrm{N}, 39.58 \%$ and $13.56 \%$ in $\mathrm{P}, 42.51 \%$ and $30.53 \%$ in $\mathrm{K}, 17.40 \%$ and $7.14 \%$ in $\mathrm{Fe}, 30.54 \%$ and $9.11 \%$ in $\mathrm{Mn}$ and $13.82 \%$ and $7.10 \%$ in $\mathrm{Zn}$ concentration in the first season. Whereas, in the second one the increases reached: $39.71 \%$ and $18.75 \%$ in TS, $32.49 \%$ and $16.36 \%$ in protein, $33.77 \%$ and $16.41 \%$ in $\mathrm{N}, 40.68 \%$ and $13.70 \%$ in $\mathrm{P}$, $31.70 \%$ and $23.90 \%$ in $\mathrm{K}, 24.26 \%$ and $10.27 \%$ in $\mathrm{Fe}, 29.67 \%$ and $13.99 \%$ in $\mathrm{Mn}$ and $11.26 \%$ and $5.83 \%$ in $\mathrm{Zn}$ concentration.

Table (13): Leaf pigments; chlorophyll a, b, total and carotenoids ( $\mathrm{mg} \mathrm{g}^{-1}$ fresh weight of bean leaves) as affected by seed quality of bean in both seasons

\begin{tabular}{|c|c|c|c|c|}
\hline \multirow{2}{*}{ Seed class } & \multicolumn{4}{|c|}{ Leaf pigments ( $\mathrm{mg} \mathrm{g}^{-1}$ fresh wt. of leaves) } \\
\hline & $\mathbf{a}$ & b & $\mathbf{T}$ & carotenoids \\
\hline \multicolumn{5}{|c|}{$\mathbf{1}^{\text {st }}$ season } \\
\hline Light & 0.805 & 0.648 & 1.576 & 0.192 \\
\hline Ungraded & 1.438 & 1.163 & 2.710 & 0.280 \\
\hline High & 1.954 & 1.505 & 3.121 & 0.341 \\
\hline $\mathbf{L S D}_{(0.05)}$ & 0.413 & 0.287 & 0.377 & 0.051 \\
\hline \multicolumn{5}{|c|}{$2^{\text {nd }}$ season } \\
\hline Light & 0.711 & 0.592 & 1.382 & 0.224 \\
\hline Ungraded & 1.347 & 1.107 & 2.549 & 0.315 \\
\hline High & 1.666 & 1.232 & 2.998 & 0.392 \\
\hline $\mathbf{L S D}_{(0.05)}$ & 0.248 & 0.111 & 0.369 & 0.061 \\
\hline
\end{tabular}

Fayoum J. Agric. Res. \& Dev., Vol. 20, No. 2, July, 2006 
BEAN SEED QUALITY: ASSOCIATED GERMINABILITY

Table (14): Chemical constituents concentration; N, P, K, Fe, Mn and Zn, protein and total sugars (TS) in bean leaves as affected by seed quality of bean in both seasons

\begin{tabular}{|c|c|c|c|c|c|c|c|c|}
\hline \multirow{2}{*}{ Seed class } & \multirow{2}{*}{$\begin{array}{c}\mathbf{N} \\
(\%)\end{array}$} & $\mathbf{P}$ & $\mathbf{K}$ & $\mathbf{F e}$ & Mn & $\mathbf{Z n}$ & protein & TS \\
\hline & & \multicolumn{5}{|c|}{ (mg $100^{-1}$ g dry matter of leaves) } & \multicolumn{2}{|c|}{$(\%)$} \\
\hline \multicolumn{9}{|c|}{$1^{\text {st }}$ season } \\
\hline Light & 2.13 & 24.0 & 207.0 & 17.64 & 5.14 & 8.61 & 13.32 & 2.65 \\
\hline Ungraded & 2.59 & 29.5 & 226.0 & 19.33 & 6.15 & 9.15 & 16.16 & 2.94 \\
\hline High & 2.89 & 33.5 & 295.0 & 20.71 & 6.71 & 9.80 & 18.07 & 3.56 \\
\hline $\mathbf{L S D}_{(0.05)}$ & 0.21 & 4.01 & 11.17 & 1.17 & $\mathbf{0 . 3 2}$ & 0.35 & 1.72 & 0.46 \\
\hline \multicolumn{9}{|c|}{$2^{\text {nd }}$ season } \\
\hline Light & 2.28 & 29.5 & 214.5 & 16.16 & 5.53 & 10.12 & 14.25 & 2.72 \\
\hline Ungraded & 2.62 & 36.5 & 228.0 & 18.21 & 6.29 & 10.64 & 16.38 & 3.20 \\
\hline High & 3.05 & 41.5 & 282.5 & 20.08 & 7.17 & 11.26 & 19.06 & 3.80 \\
\hline $\mathbf{L S D}_{(0.05)}$ & 0.43 & 3.91 & 10.70 & 1.03 & 0.69 & 0.41 & 1.09 & 0.49 \\
\hline
\end{tabular}

\section{In green pods.}

Regarding the changes of chemical constituents in green pods of bean, data presented in Table (15), show that there are significant differences between the different seed classes in both seasons for TS, protein, $\mathrm{N}, \mathrm{P}, \mathrm{K}, \mathrm{Fe}, \mathrm{Mn}$ and $\mathrm{Zn}$ concentrations. It is clear that the heavy class of seed resulted in a marked increase in the levels of those chemical constituents over that of light and ungraded classes. This finding seems to indicate that chemical constituents of green pods affected by seed quality class. However, the increases recorded by the heavy seed over light and ungraded classes were $37.76 \%$ and $22.05 \%$ in TS , $28.91 \%$ and $3.76 \%$ in protein, $28.48 \%$ and $3.74 \%$ in $\mathrm{N}, 23.71 \%$ and $13.21 \%$ in $\mathrm{P}, 16.12 \%$ and $5.62 \%$ in $\mathrm{K}, 13.84 \%$ and $11.04 \%$ in $\mathrm{Fe}, 27.18 \%$ and $18.02 \%$ in $\mathrm{Mn}$ and $37.91 \%$ in $\mathrm{Zn}$ concentration in the first season. Meanwhile, in the second one increases reached: $39.84 \%$ and $22.86 \%$ in TS , $32.12 \%$ and $10.75 \%$ in protein, $32.11 \%$ and $10.75 \%$ in $\mathrm{N}, 22.83 \%$ and $11.88 \%$ in $\mathrm{P}, 23.38 \%$ and $8.26 \%$ in $\mathrm{K}, 19.21 \%$ and $5.88 \%$ in $\mathrm{Fe}, 31.48 \%$ and $17.36 \%$ in $\mathrm{Mn}$ and $40.74 \%$ and $21.91 \%$ in $\mathrm{Zn}$ concentration.

Table (15): Chemical constituents concentration; N, P, K, Fe, Mn and Zn, protein and total sugars (TS) in dry matter of bean green pods as affected by seed quality of bean in both seasons

\begin{tabular}{|c|c|c|c|c|c|c|c|c|}
\hline \multirow{2}{*}{ Seed class } & \multirow{2}{*}{$\begin{array}{c}\mathbf{N} \\
(\%)\end{array}$} & $\mathbf{P}$ & $\mathbf{K}$ & Fe & Mn & $\mathbf{Z n}$ & protein & TS \\
\hline & & \multicolumn{5}{|c|}{ (mg $100^{-1} \mathrm{~g}$ dry matter of green pods) } & \multicolumn{2}{|c|}{$(\%)$} \\
\hline \multicolumn{9}{|c|}{$1^{\text {st }}$ season } \\
\hline Light & 1.51 & 97 & 291.5 & 0.795 & 1.03 & 14.64 & 9.41 & 2.41 \\
\hline Ungraded & 1.87 & 106 & 320.5 & 0.815 & 1.11 & 17.71 & 11.69 & 2.72 \\
\hline High & 1.94 & 120 & 338.5 & 0.905 & 1.31 & 20.19 & 12.13 & 3.32 \\
\hline $\mathbf{L S D}_{(0.05)}$ & 0.04 & 6.13 & 11.17 & 0.67 & 0.14 & 1.31 & 0.40 & 0.25 \\
\hline \multicolumn{9}{|c|}{$2^{\text {nd }}$ season } \\
\hline Light & 1.56 & 92 & 305.8 & 0.755 & 1.08 & 14.63 & 9.75 & 2.46 \\
\hline Ungraded & 1.86 & 101 & 348.5 & 0.850 & 1.21 & 16.89 & 11.63 & 2.80 \\
\hline High & 2.06 & 113 & 377.3 & 0.900 & 1.42 & 20.59 & 12.88 & 3.44 \\
\hline $\mathbf{L S D}_{(0.05)}$ & 0.15 & 7.01 & 15.01 & 0.031 & 0.16 & 2.13 & 0.32 & 0.18 \\
\hline
\end{tabular}

Fayoum J. Agric. Res. \& Dev., Vol. 20, No. 2, July, 2006 
In dry seed.

Data presented in Table (16) show that a high quality of bean seed resulted in a marked increase in level of the chemical constituents in dry seeds; Total soluble carbohydrates (TSC), protein, N, P, K, Fe, Mn and Zn. The increase affect was more pronounced in the dry seeds of heavy seed class which had been a significant increase as compared to both of light and ungraded seed classes in both seasons. This increase, in the first season, reached: $12.15 \%$ and $5.49 \%$ in TSC, $27.30 \%$ and $10.89 \%$ in protein, $27.16 \%$ and $10.86 \%$ in $\mathrm{N}, 43.64 \%$ and $16.18 \%$ in $\mathrm{P}, 48.84 \%$ and $23.08 \%$ in $\mathrm{K}$, $22.22 \%$ and $11.59 \%$ in $\mathrm{Fe}, 16.44 \%$ and $5.59 \%$ in $\mathrm{Mn}$ and $27.91 \%$ and $10.00 \%$ in $\mathrm{Zn}$ concentration. Whereas, the increases in the second season, were; $18.69 \%$ and $9.18 \%$ in TSC, $25.17 \%$ and $8.92 \%$ in protein, $25.17 \%$ and $9.21 \%$ in $\mathrm{N}, 53.85 \%$ and $23.08 \%$ in $\mathrm{P}, 53.45 \%$ and $23.61 \%$ in $\mathrm{K}, 19.16 \%$ and $8.57 \%$ in $\mathrm{Fe}, 12.42 \%$ and $4.29 \%$ in $\mathrm{Mn}$ and $21.88 \%$ and $23.53 \%$ in $\mathrm{Zn}$ concentration. In this respect, larger seed weight positively correlated with seed N, P and K in cowpea (Kang and Ofeimu, 1993).

Table (16): Chemical constituents concentration; N, P, K, Fe, Mn and $\mathrm{Zn}$, protein and total soluble carbohydrates (TSC) in dry seeds of bean as affected by seed quality of bean in both seasons

\begin{tabular}{|c|c|c|c|c|c|c|c|c|}
\hline \multirow{2}{*}{ Seed class } & \multirow{2}{*}{$\begin{array}{c}\mathbf{N} \\
(\%)\end{array}$} & $\mathbf{P}$ & $\mathbf{K}$ & $\mathbf{F e}$ & Mn & $\mathbf{Z n}$ & protein & TSC \\
\hline & & \multicolumn{5}{|c|}{ (mg $100^{-1} \mathrm{~g}$ dry matter of dry seeds) } & \multicolumn{2}{|c|}{$(\%)$} \\
\hline \multicolumn{9}{|c|}{$1^{\text {st }}$ season } \\
\hline Light & 3.13 & 55 & 172 & 126.0 & 73.0 & 43.0 & 19.54 & 56.06 \\
\hline Ungraded & 3.59 & 68 & 208 & 138.0 & 80.5 & 50.0 & 22.41 & 59.60 \\
\hline High & 3.98 & 79 & 256 & 154.0 & 85.0 & 55.0 & 24.85 & 62.87 \\
\hline $\mathbf{L S D}_{(0.05)}$ & 0.30 & 8.12 & 33.15 & 11.01 & 3.07 & 3.67 & 1.92 & 2.03 \\
\hline \multicolumn{9}{|c|}{$2^{\text {nd }}$ season } \\
\hline Light & 3.22 & 52 & 174 & 143.5 & 76.5 & 48.0 & 20.10 & 52.10 \\
\hline Ungraded & 3.69 & 65 & 216 & 157.5 & 81.5 & 52.5 & 23.10 & 56.64 \\
\hline High & 4.03 & 80 & 267 & 171.0 & 86.0 & 62.0 & 25.16 & 61.84 \\
\hline $\operatorname{LSD}_{(0.05)}$ & 0.24 & 10.02 & 37.11 & 10.31 & 3.77 & 6.09 & 1.12 & 3.13 \\
\hline
\end{tabular}

Finally, based on the consistent results in this study, it is our opinion that weight-grading (separation) of bean seed can be used to improve low quality commercial seed. In addition, it is likely that farmers will obtain a good germination, growth and yield by sowing bean seeds high weight (heavy). It is recommended that high quality seeds must be used to reduced the risk of stand establishment failure and ensure full yield of bean (green pods and dry seeds).

\section{REFERENCES:}

Abdul-Baki, A.A. and J.D. Anderson (1973).Vigor determination in soybean by multiple criteria. Crop Sci., 13: 630-633.

Al-Mukhtar, F.A. and D.P. Coyne (1981). In heritance and association of flower, ovule, seed, pod and maturity characters in dry edible beans Phaseolus vulgaris L. J. Amer. Soc. Hort. Sci., 106: 713-719.

AOAC (1990). Association of Official Analytical Chemists. Official Methods of Analysis. $15^{\text {th }}$ ed. Washington, D.C.

Arnon, D.I. (1949). Copper enzymes in isolated chloroplast polyphenoloxidase in Beta vulgaris L. Plant Physiol., 24: 1-5.

Fayoum J. Agric. Res. \& Dev., Vol. 20, No. 2, July, 2006 
BEAN SEED QUALITY: ASSOCIATED GERMINABILITY

Bartee, S.N. and D.R. Krieg (1974). Cotton and density: Associated physical and chemical properties of 10 cultivars. Agron. J., 66: 433435.

Black, C.A. (1965). Methods of soil analysis. Amer. Soc. Agron. Madison, Wis.

Brakke, M.P. and F.P. Gardner (1987). Juvenile growth in pigeon pea, soybean and cowpea in relation to seed and seedling characteristics. Crop Sci., 27: 311-316.

Bredemeier, C.; C.M. Mundstock and D. Buttenbender (2001). Effects of seed size on initial plant growth and grain yield of wheat. Pesoquisa, Agropecuaria, Brasileira, 36(8): 1016-1068.

Burris, J. S.; O.T. Edje and A.H. Wahab (1973). Effects of seed size on seedling performance in soybeans: II. Seedling growth, photosynthesis and field performance. Crop Sci., 13(3-4): 207-212.

Champman, H.D. and P.F. Pratt (1961). Methods of Analysis for Soil, Plants and Waters. Univ. Calif., D.V., Agric. Sci., USA.

Chen, P.S.; T.Y. Toribara and H. Warner (1956). Assay of inorganic phosphate, total phosphate and phosphatases. Anal. Chem., 28: 1756-1769.

Das, S.N. and B.N. Chatterjee (1992). Effect of seed size on the growth, yield and root attributes of kidney bean (Phaseolus vulgaris L.). Indian J. Pulses Res., 5(2): 156-159.

Dubois, M.F.; K.A. Gilles; J.K. Hamiton and P.A. Robers and F.Smith (1956). Colorimetric methods for determination of sugars and related substances. Anal. Chem., 28: 350-354.

Duke, S. H.; G. Kakefuda and T.M. Harvey (1983). Differential leakage of intracellular substances from imbibing soybean seeds. Plant Physiol., 72: 919-924.

Fernandez, G.C.J. and J.C. Miller (1985). Yield component analysis in five cowpea cultivars. J. Amer. Soc. Hort. Sci., 110:553-559.

Fontes, L.A.N. and A.J. Ohlrogge (1972). Influence of seed size and population on yield and other characteristics of soybean (Glysin max (L.) Merr.). Agron. J., 64: 833-836

Gadallah, F.M. (2000). Seed density in relation to germination and seedling quality in cotton (Gossypium barbadense L.). Alex. J. Agric. Res., 45(2): 119-137.

Gray, D. and J.R.A. Steckel (1986). The effects of seed-crop plant density, transplant size, harvest date and seed grading on leek (Allium porrum L.) seed quality. J. Hort. Sci., 61(3): 315-323.

Hafez, A.R. and D.S. Mikkelsen (1981). Colorimetric determination of nitrogen for evaluation the nutritional status of rice. Commun. Soil Sci. and Plant Analysis, 12(1): 16-69.

ISTA (1966). The International Seed Testing Association. International Rules for Seed Testing. Proc. Int. Seed. Test. Assoc., 31: 1-152.

Jackson, M.L. (1967). Soil Chemical Analysis. Prentice-Hall of India, pp.144-197.

Johnson, R.R. and D.L. Mulvaney (1980). Development of a model for use in maize replant decision. Agron. J., 72: 459-464.

Kang, B.T. and M.O. Ofeimu (1993). Seed size and fertilizer effects on seedling growth of contrasting plant species. Plant Nutrition from Genetics Engineering to Field Practice: Proceedings of $12^{\text {th }}$

Fayoum J. Agric. Res. \& Dev., Vol. 20, No. 2, July, 2006 
International Plant Nutrition Colloquium, 21-26 September, Perth Western, Australia, 349-352.

Kelley, J.D. and F.A. Bliss (1975). Heritability estimates of percentage seed protein and available methionine and correlations with yield in dry bean. Crop Sci., 15: 753-757.

King, E.E. and G.E. Lamkin (1979). Uniform quality cotton seed for laboratory and field use. p.32. In Proc. Beltwide Cotton Prod. Conf. Phoenix, Ariz., 7-11 January. National Cotton Council, Memphis, Tenn.

Krieg, D.R. and S.N. Bartee (1975). Cotton and density: associated germination and seedling emergence properties. Agron. J., 67: 343-347.

Maranville, J. W. and M. D. Clegg (1977). Influence of seed size and density on germination, seedling emergence and yield of grain sorghum. Agron. J., 69(3-4): 329-330.

Naylor, R.E.L. (1993). The effect of parent plant nutrition on seed size, viablitiy and vigour on germination of wheat and tritical at different temperatures. Ann. Appl. Biol., 123(2): 379-390.

Ondrej, M. (1984). The effect of pea seed quality on the yield and plant health. Rostlinna Vyroba, 30(5): 497-504.

Page, A.I.; R.H. Miller and D.R. Keeney (1982). Methods of Soil Analysis. Part II. Chemical and Microbiological Methods. $2^{\text {nd }}$ ed. Amer. Soc. Agron., Madison, Wisconsin, USA.

Perin, A.; A.P. Araujo and M.G. Teixeria (2002). Effect of seed size on biomass and nutrient accumulation and on grain yield of common bean. Pesquisa Agropecuaria Brasileira, 37(12): 1711-1718.

Piper, C. S. (1947). Soil and Plant Analysis. The University of Adelaide, Adelaide. Australia.

Qiu, J. and J.A. Mosjidis (1993). Influence of seed weight and planting depth on common vetch establishment and growth. Field Crop Research, 33: 353-366.

Rodo, A.B. and J. F. Marcos (2003). Onion seed vigor in relation to plant growth and yield. Horticltura Brasil., 21(2): 1-12.

Rosein, H. (1957). A modified ninhydrin colorimetric analysis for amino acids. Arch. Biochem. Biophys., 67: 10-15.

Salih, F.A. (1983). Influence of sowing date, seed rate, and seed size on yield and yield components of faba bean. Fabis Newsletter, Faba Bean Information Service, ICARDA, 7:32-41.

Sayed, G.; D.A. Smittle; H.A. Mills and G.I. Banna (1990). Onion seed size, weight and elemental content affect germination and bulb yield. HortSci., 25(5): 522-523.

Smith, T.J. and H.M. Camper (1975). Effects of seed size on soybean performance. Agron. J., 67: 681-684.

Smittle, D.A. (1982). Radish (Raphanus sativus) growth and yield responses to seed grading by size and aspiration. Seed Sci.\& Technol., 10: 199-205.

Smittle, D.A.; R.E. Williamson and J.R. Stansell (1976). Response of snap beans to seed separation by acrodynamic properties. HortSci., 11: 469-471.

Snedecor, W.C. and W.G. Cochran (1980). Statistical Methods. $7^{\text {th }}$ ed. The Iowa State Univ. Press, Ames, Iowa, USA.

Fayoum J. Agric. Res. \& Dev., Vol. 20, No. 2, July, 2006 
BEAN SEED QUALITY: ASSOCIATED GERMINABILITY

Stivers, R.K. and M.I. Sweeringin (1978). Soybean yield compensation with different populations and missing plant patterns. Agron. J., 72: $98-102$.

Tekrony, D.M. and D.B. Egli (1991). Relationship of seed vigor to crop yield: a review. Crop Sci., 31(4): 816-822.

Westermann, D.T. and S.E. Crothers (1977). Plant population effects on the seed yield components of bean. Crop Sci., 17: 493-496.

Yadava, R.B.R. (1990). Effect of seed size and weight on plant growth and yield of various genotypes of cowpea. Proceedings of the International Congress of plant Physiology, New Delhi, India, 1520 February, 1: 333-335.

Zaimoglu, B.; H.H. Arioglu and M. Arslan (2004). Effects of seed quality on plant population and seed yield of double cropped soybean in the Mediterranean region of Turkey. Asian J. Plant Sci., 3(5): 574577.

جودة بذور الفاصوليا وعلاقتها بالقدرة الإنباتية والكفاعة الحقلية

فاروق محمد جادادلة - الله

قسم النبات الزراعى- كلية الزراعة- جامعة الفيوم- مصر

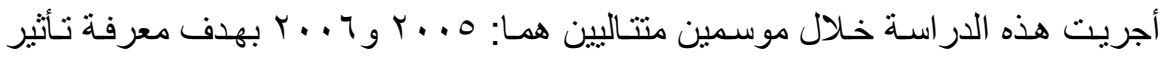

المستويات المختلفة لجودة بذور الفاصوليا على القدرة الإنباتية (در اسة معملية) و النمو و المحصدول

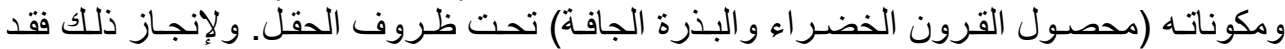

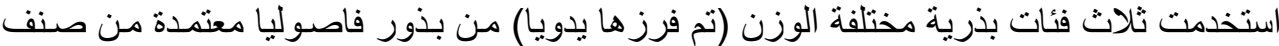

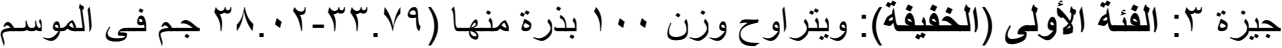

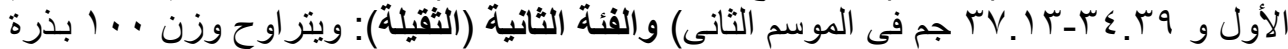

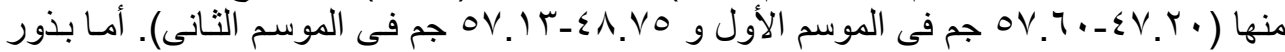

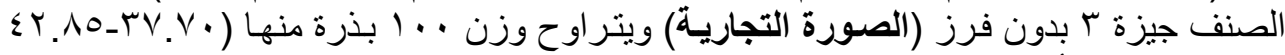

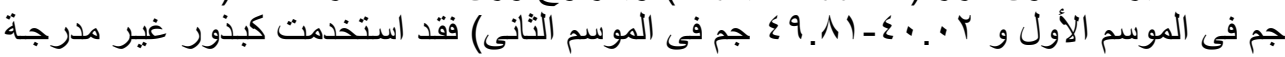

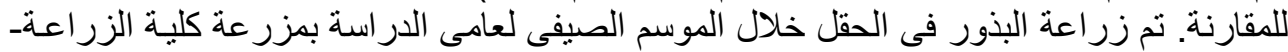

$$
\text { ويمكن تلخيص النتائج المتحصل عليها فيمان فيما يلى: }
$$

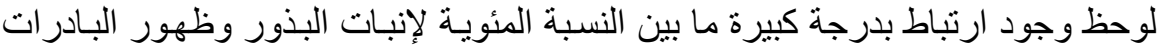

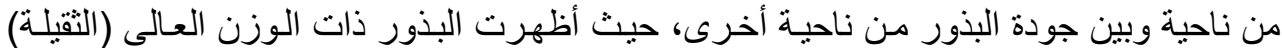

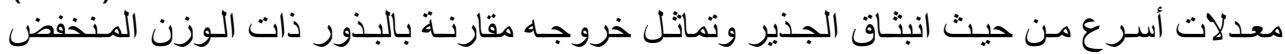

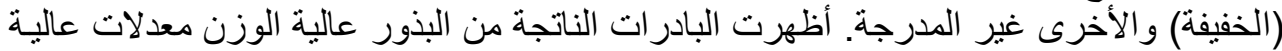

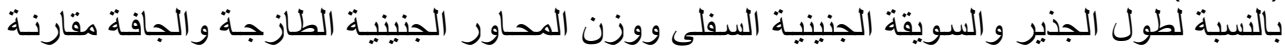

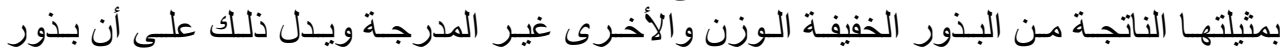

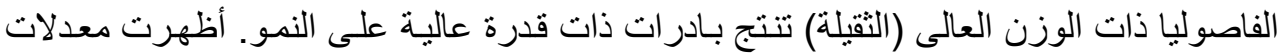

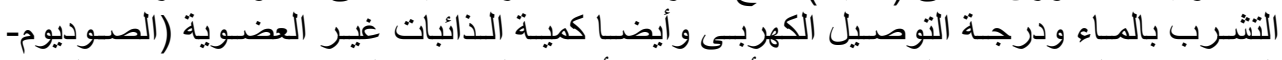

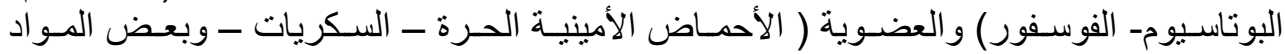

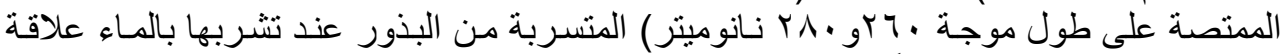

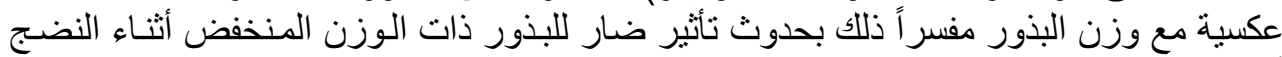

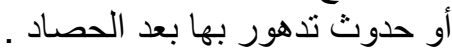

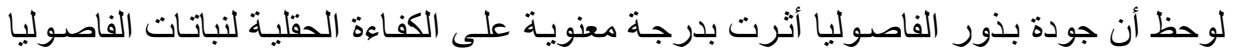

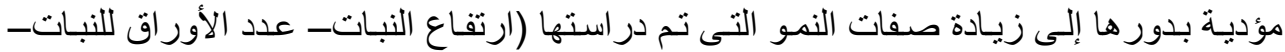

Fayoum J. Agric. Res. \& Dev., Vol. 20, No. 2, July, 2006 


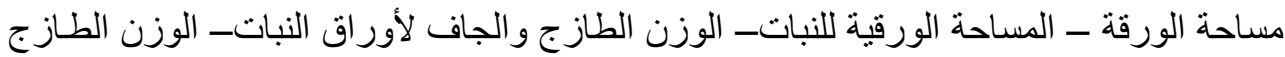

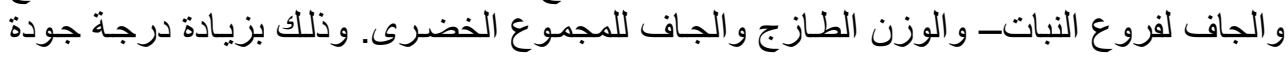

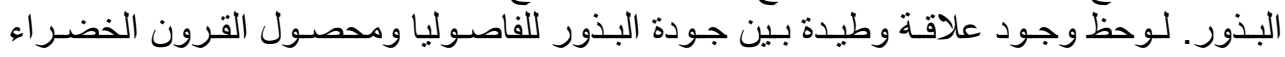

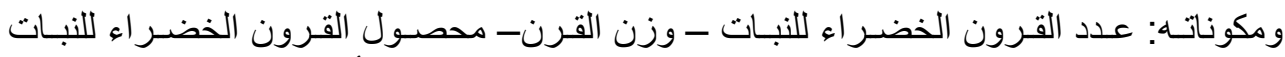

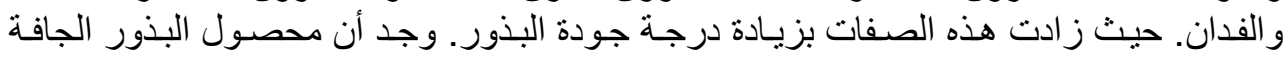

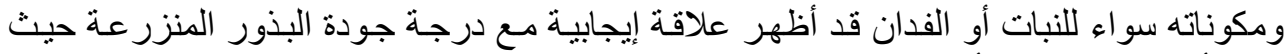

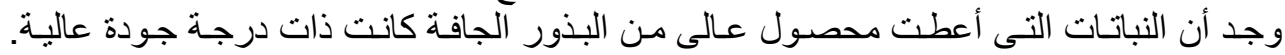

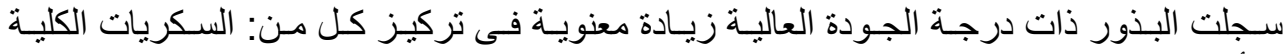

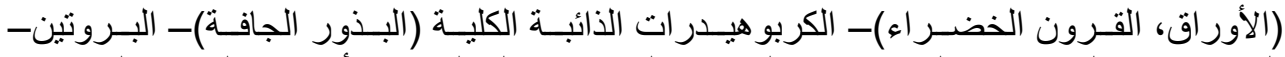

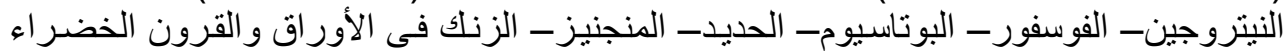

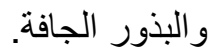

وأخيرا، وفى ضوء الجئ النتائج السابقة، أن عملية فصل (تدريج) بذور الفاصوليا إلى الفئات السابقة

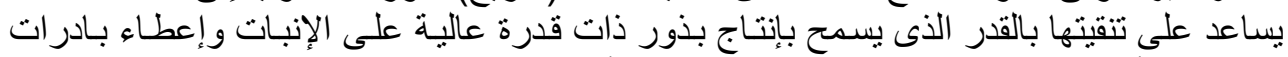

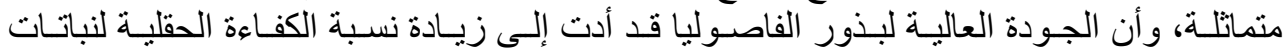

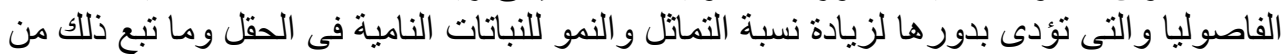

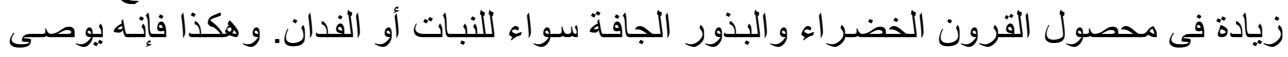

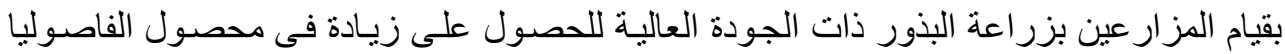
(القرون الخضر اءع والبذور الجافة).

Fayoum J. Agric. Res. \& Dev., Vol. 20, No. 2, July, 2006 